\title{
PROFIL KROMATOGRAFI LAPIS TIPIS HERBA SAMBILOTO (Andrographis paniculata Nees.)
}

\section{THIN LAYER CHROMATOGRAPHY PROFILE OF SAMBILOTO (Andrographis paniculata Nees.) HERB}

\author{
Muhammad Yani Zamzam \\ Sekolah Tinggi Farmasi Muhammadiyah Cirebon \\ Jl Cideng Indah no 3 Cirebon
}

Submitted : 20 April 2019 Reviewed : 19 August 2019 Accepted : 28 September 2019

\begin{abstract}
ABSTRAK
Sambiloto (Andrographis paniculata Nees.) adalah salah satu tanaman obat terpenting dalam sistem pengobatan tradisional Cina dan Ayurveda. Telah dilakukan penelitian pendahuluan terhadap herba sambiloto yang meliputi determinasi tanaman, uji kadar air, uji kadar abu, dan profil kromatografi lapis tipis dari ekstrak-ekstrak yang dihasilkan secara maserasi. Kadar air simplisia herba sambiloto adalah $12,71 \% \mathrm{~b} / \mathrm{b}$ sedangkan kadar abu adalah 8,99 \% b/b. Dengan metode maserasi, rendemen ekstrak $n$ heksana, ekstrak etil asetat, dan ekstrak metanol berturut-turut adalah $0,40 \% \mathrm{~b} / \mathrm{b}, 7,67 \% \mathrm{~b} / \mathrm{b}$, dan $4,61 \%$ b/b. Sedangkan endapan yang terdapat dalam ekstrak etil asetat sebanyak 2,17\% $\mathrm{b} / \mathrm{b}$ dan endapan dalam ekstrak metanol sebanyak $0,93 \% \mathrm{~b} / \mathrm{b}$. Sistem kromatografi yang baik menggunakan fase diam silika gel GF 254 dengan fase gerak $n$-heksana-etil asetat (5:1) untuk ekstrak $n$-heksana dan fase gerak kloroform-metanol (5:1) untuk ekstrak etil asetat maupun ekstrak metanol.
\end{abstract}

Kata kunci : Sambiloto; Andrographis paniculata Nees.; maserasi, rendemen, kromatografi lapis tipis

\begin{abstract}
Sambiloto (Andrographis paniculata Nees.) is one of the most important of herbal medicine plant on China and Ayurveda traditional medication . Based on research of sambiloto herb which determination of plant, water content test, ash content test, and thin layer chromatography profile of extracts from maceration process. Water content of sambiloto herb is $12,71 \% \mathrm{w} / \mathrm{w}$ meanwhile ash content is $8,99 \% \mathrm{w} / \mathrm{w}$. With maceration process yield extraction of $n$-hexane extract, ethyl acetate extract, and methanol exctract are $0,40 \% \mathrm{w} / \mathrm{w}$, $7,67 \% \mathrm{w} / \mathrm{w}$, dan $4,61 \% \mathrm{w} / \mathrm{w}$, respectively. While sediment on ethyl acetate extract is 2,17 $\% \mathrm{w} / \mathrm{w}$ and sediment on methanol extract is $0,93 \% \mathrm{w} / \mathrm{w}$. A good chromatography system is using silica gel GF 254 as stationary phase with mixture of $n$-hexane-ethylacetate (5:1) for $n$ hexane extract and mixture of chloroform-methanol (5:1) for ethylacetate extract and methanol extract as mobile phase.
\end{abstract}

Keywords: Sambiloto; Andrographis paniculata Nees.; maceration, yield extraction, thin layer chromatography 


\section{Penulis korespondensi:}

Muhammad Yani Zamzam

Sekolah Tinggi Farmasi Muhammadiyah Cirebon

Jl Cideng Indah no 3 Cirebon

Email: myanizamzam@gmail.com /082 295103377

\section{PENDAHULUAN}

Sambiloto (Andrographis paniculata Nees.) adalah salah satu tanaman obat terpenting dalam sistem pengobatan tradisional Cina dan Ayurveda yang digunakan secara luas untuk mengobati gangguan perut, penyakit-penyakit infeksi dan influenza. Hasil studi farmakologi dan klinis menunjukkan bahwa sambiloto memiliki aktivitas antiinflamasi, antialergi, imunostimulan, antivirus, antioksidan, hepatopratektif, kardiovaskular, dan lainlain $(1,2,3)$. Kandungan kimia utama dari herba sambiloto adalah senyawa-senyawa diterpenoid dan flavonoid yang diyakini bertanggung jawab terhadap aktivitas farmakologinya (1). Lebih dari 20 senyawa diterpenoid dan lebih dari 10 senyawa flavonoid telah dilaporkan terdapat dalam herba sambiloto $(1,2,3)$.

Penelitian awal ini meliputi determinasi tanaman, uji kadar air, uji kadar abu, dan profil kromatografi lapis tipis (KLT) dari ekstrak-ekstrak yang dihasilkan. Herba sambiloto dimaserasi secara bertahap berturut-turut dengan $n$-heksana, etil asetat, dan metanol.

\section{METODE PENELITIAN}

\section{Alat dan Bahan}

a. Alat

Bejana maserasi, alat kromatografi lapis tipis, penguap putar vakum, oven, hot plate, timbangan analitik, desikator, alat Karl Fischer, tanur, krus silikat.

b. Bahan

Simplisia herba sambiloto yang berasal dari kebun tanaman Pusat Aplikasi Teknologi Isotop dan Radiasi (PATIR) Badan Tenaga Nuklir Nasional (BATAN) Pasar Jumat, Jakarta Selatan, $n$-heksana (Teknis, Bratachem), etil asetat (Teknis, Bratachem),metanol (Teknis, Bratachem), serium sulfat, asam sulfat pekat, pelat silika gel GF 254 Merck, kloroform (Teknis, Bratachem), pereaksi Karl Fischer.

\section{Jalannya Penelitian}

a. Tempat penelitian

Penelitian dilakukan di Laboratorium Bahan Kesehatan Pusat Aplikasi Teknologi Isotop dan Radiasi (PATIR) BATAN Pasar Jumat, Jakarta Selatan dan Laboratorium Kimia Universitas Pancasila Jakarta. Determinasi tanaman dilakukan di Herbarium Bogoriense, Pusat Penelitian Biologi Lembaga Ilmu Pengetahuan (LIPI) Cibinong.

b. Penentuan kadar air (4)

Lebih kurang $20 \mathrm{~mL}$ metanol dimasukkan ke dalam labu titrasi, lalu dititrasi dengan pereaksi Karl Fischer hingga titik akhir tercapai. Sejumlah bahan yang ditimbang saksama yang diperkirakan mengandung $10 \mathrm{mg}$ sampai $50 \mathrm{mg}$ air dimasukkan kedalam labu titrasi, aduk selama 1 menit, kemudian dititrasi dengan pereaksi Karl Fischer yang telah diketahui kesetaraan airnya.

c. Penentuan kadar abu (4)

Lebih kurang 2 g sampai 3 g zat yang telah digerus dan ditimbang saksama, dimasukkan ke dalam krus platina atau krus silikat yang telah dipijarkan dan ditara. 
Bahan diratakan, kemudian dipijarkan perlahan-lahan hingga arang habis, didinginkan dan ditimbang. Jika dengan cara ini arang tidak dapat dihilangkan, ditambahkan air panas kemudian disaring melalui kertas saring bebas abu. Sisa dan kertas saring dipijarkan dalam krus yang sama. Filtrat dimasukkan ke dalam krus kemudian diuapkan dan dipijarkan hingga bobot tetap. Kadar abu dihitung terhadap bahan yang telah dikeringkan di udara.

d. Ekstraksi

Sejumlah $1.000 \mathrm{~g}$ serbuk herba sambiloto dimaserasi dengan $12 \mathrm{~L} n$-heksana sambil diaduk dengan kecepatan 350-360 rpm selama lebih kurang 5 jam. Maserat dibiarkan semalaman, kemudian diaduk kembali selama lebih kurang 4 jam. Maserat disaring, filtrat dipekatkan dalam rotavapor, ampas dimaserasi kembali dengan $n$ heksana dan dibiarkan semalaman dengan sesekali diaduk. Maserasi dengan $n$-heksana dihentikan jika maserat sudah sangat encer. Maserat disaring, filtrat dipekatkan. Ekstrak yang diperoleh diuapkan pelarutnya dengan rotavapor kemudian dimasukkan ke dalam desikator hampa dan ditimbang sebagai ekstrak $n$-heksana. Ampas dimaserasi dengan lebih kurang $4 \mathrm{~L}$ etil asetat, maserat dibiarkan semalaman dengan sesekali diaduk. Maserat disaring, filtrat dipekatkan, endapan yang terbentuk dipisahkan, dan selanjutnya disebut sebagai endapan etil asetat. Pengulangan maserasi dilakukan sampai maserat sangat encer. Ekstrak dan endapan yang diperoleh diuapkan pelarutnya dengan rotavapor kemudian dalam desikator hampa dan ditimbang sebagai ekstrak etil asetat dan endapan etil asetat. Ampas dimaserasi dengan lebih kurang $4 \mathrm{~L}$ metanol, maserat dibiarkan semalaman dengan sesekali diaduk. Maserat disaring, filtrat dipekatkan, endapan yang terbentuk dipisahkan, dan selanjutnya disebut endapan metanol. Pengulangan maserasi dilakukan sampai maserat sangat encer. Ekstrak dan endapan yang diperoleh diuapkan pelarutnya dengan rotavapor kemudian dalam desikator hampa dan ditimbang sebagai ekstrak metanol dan endapan metanol.

e. Kromatografi Lapis Tipis (KLT)

Analisis KLT dilakukan terhadap ekstrak $n$-heksana, etil asetat, dan metanol, juga endapan etil asetat dan metanol. Analisis KLT juga dilakukan pada fraksi-fraksi hasil fraksinasi dengan kolom kromatografi maupun hasil pemurnian isolat dengan cara KLT semi preparatif.

Dalam penelitian ini fase diam yang digunakan adalah silika gel $\mathrm{GF}_{254}$ dan fase gerak bervariasi tergantung pada tingkat kepolaran komponen senyawa yang akan dipisahkan. Deteksi dilakukan di bawah sinar UV $254 \mathrm{~nm}$ dan $366 \mathrm{~nm}$ serta dengan cara disemprot dengan pereaksi serium sulfat dalam asam sulfat $1 \%$ kemudian pelat dipanaskan pada hot plate, untuk kemudian direkam.

\section{Analisis Data}

Data berupa data deskriptif hasil determinasi tanaman, hasil uji kadar air, hasil uji kadar abu, rendemen ekstrak, dan hasil KLT.

\section{HASIL DAN PEMBAHASAN}

Tanaman yang digunakan adalah sambiloto dengan nama latin Andrographis paniculata Nees. Kadar air simplisia adalah $12,71 \%$ b/b yang masih masuk dalam rentang kadar air simplisia yaitu $8-14 \%$ b/b. Kadar abu simplisia adalah $8,99 \%$ b/b yang berarti memenuhu syarat menurut Materia Medika Indonesia (MMI) yaitu tidak lebih dari $12 \%$. Hal ini menunjukkan bahwa bahan uji tidak mengandung pencemar anorganik dalam jumlah yang besar. Herba sambiloto yang diekstraksi secara bertahap diperoleh masingmasing ekstrak $n$-heksana sebanyak 3,9809 g, ekstrak etil asetat 76,7108 g dengan sejumlah 21,6829 berupa endapan yang dipisahkan pada waktu pemekatan ekstrak 
etil asetat, dan ekstrak metanol sebanyak 46,0728 g dengan sejumlah 9,3142 g berupa endapan metanol yang dipisahkan pada waktu pemekatan ekstrak metanol.

Hasil penelitian menunjukkan bahwa bobot ekstrak terbesar adalah ekstrak etil asetat yang mungkin merupakan senyawa-senyawa semipolar, sedangkan senyawa-senyawa non polar merupakan bagian yang paling kecil. Secara lengkap hasil ekstraksi herba sambiloto dapat dilihat pada Tabel I.

Tabel I. Hasil ekstraksi herba sambiloto dan rendemen yang dihasilkan

\begin{tabular}{|c|l|c|c|}
\hline No & \multicolumn{1}{|c|}{ Ekstrak/endapan } & Bobot ( g ) & Rendemen (\%) \\
\hline 1 & Ekstrak $n$-heksana & 3,9809 & 0,40 \\
\hline \multirow{2}{*}{2} & Ekstrak etil asetat & 76,7108 & 7,67 \\
\cline { 2 - 4 } & $\begin{array}{l}\text { Endapan etil asetat yang telah } \\
\text { dipisahkan dari ekstrak }\end{array}$ & 21,6829 & 2,17 \\
\hline \multirow{2}{*}{3} & \begin{tabular}{l} 
Ekstrak metanol \\
\cline { 2 - 4 }
\end{tabular} & $\begin{array}{l}\text { Endapan metanol yang telah } \\
\text { dipisahkan dari ekstrak }\end{array}$ & $9,0,0728$ \\
\hline
\end{tabular}

Hasil analisis KLT ekstrak $n$-heksana, ekstrak etil asetat, endapan etil asetat, ekstrak metanol, dan endapan metanol dapat dilihat pada Gambar 1. Berdasarkan kromatogram tersebut dapat disimpulkan bahwa pengembang terbaik untuk memisahkan ekstrak $n$-heksana adalah campuran $n$-heksana-etil asetat (5:1), sedangkan pengembang terbaik untuk memisahkan ekstrak etil asetat dan ekstrak metanol adalah campuran kloroform-metanol (5:1). Disamping itu dari kromatogram (b) dapat dilihat bahwa endapan etil asetat sudah hampir murni, sehingga pada tahap berikutnya akan dimurnikan lebih lanjut. Sedangkan endapan metanol dengan pengembang kloroform-metanol (5:1) tidak nampak bercak di bawah sinar UV, yang menunjukkan perlu pengembang yang lebih polar atau fase balik, juga menunjukkan senyawa yang terdapat dalam endapan metanol tidak mempunyai gugus kromofor.
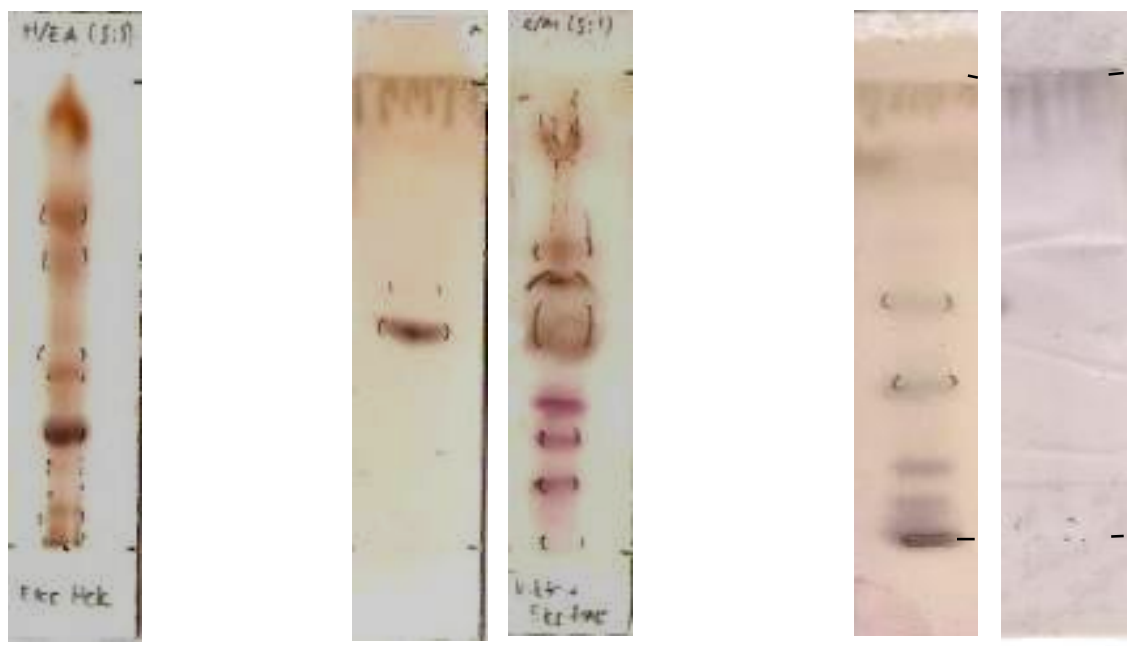

Gambar 1. Hasil KLT ekstrak $n$-heksana, ekstrak etil asetat, dan endapan etil asetat 
Keterangan :

(a) Ekstrak $n$-heksana

(b) Endapan etil asetat

(c) Ekstrak etil asetat + endapan etil asetat

(d) Ekstrak metanol

(e) Endapan metanol

Fase diam : Silika gel $\mathrm{GF}_{254}$

Fase gerak : $n$-Heksana-etil asetat (5:1) (a);

Kloroform-metanol (5:1) (b-e)

Kromatogram di atas dapat dijadikan dasar untuk mengisolasi senyawa yang terdapat dalam eksrak $n$-heksana, ekstrak etil asetat, maupun ekstrak metanol sekaligus dapat dipandu analisis ini dengan uji aktivitas, mengingat sistem kromatografi yang cocok telah diketahui.

\section{KESIMPULAN}

Sistem kromatografi yang baik menggunakan fase diam silika gel GF 254 dengan fase gerak $n$-heksana-etil asetat (5:1) untuk ekstrak $n$-heksana dan fase gerak kloroformmetanol (5:1) untuk ekstrak etil asetat maupun ekstrak metanol.

\section{DAFTAR PUSTAKA}

Wenkui L, Xudong Xu, dan Hongjie Z. 2007 Secondary metabolites from Andrographis paniculata. Chem. Pharm. Bull.; 55(3):455-458.

Herba Andrographidis, WHO Monographs on Selected Medicinal Plants, http://villageherbalist.co.uk/lowershaw/WHO, diakses 18 April 2008.

Kardono, LBS, Artanti N, Dewiyanti ID, Basuki T. 2003. Selected Indonesian medicinal plants: Monographs and descriptions. Volume 1. Jakarta: Grasindo.113 - 166

.Departemen Kesehatan Republik Indonesia. 1979. Materia Medika Indonesia. Jilid III. Jakarta: Direktorat Jenderal Pengawasan Obat dan Makanan. 20-25. 
